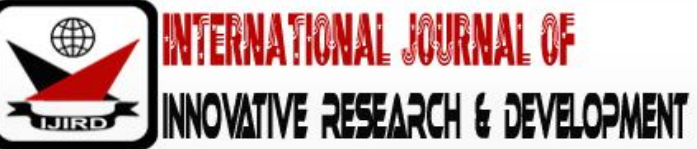

ISSN 2278 - 0211 (Online)

\section{Allocative Efficiency in Layer and Broiler Production in Sokoto State, Nigeria}

Musa Dalhatu
Ahmed Ladan Ala
Lecturer, Department of Agricultural Technology, Umaru Ali Shinkafi Polytechnic, Nigeria
Bhocturer, Department of Agricultural Economics, Usmanu Danfodio University, Nigeria
Bello Kudan Gambo
E. A. G. Manza
Lecturer, Department of Agricultural Economics and Extension, Kaduna State University, Nigeria
Idris Abdulrauf Kassim
Lecturer, Department of Agricultural Economics and Extension, Kaduna State University Nigeria
Lecturer, Department of Agricultural Economics and Extension, Kaduna State University, Nigeria

\begin{abstract}
:
The study was conducted to among others, to examine the allocative efficiency of layer and broiler enterprises in Sokoto State. Stochastic frontier production function was used to analyse the data. Farm level survey data from 135 each of layer and broiler farmers were obtained using well-structured questionnaire between June and November, 2013. The parameters were estimated simultaneously with those of the model of inefficiency effects using the maximum likelihood estimation technique. The study revealed that the farmers were not fully allocatively efficient in their production activities, with mean allocative efficiency of 0.91 and 0.80 for layer and broiler farmers, respectively. The study further revealed that the farmers were constrained with problems of insufficient capital, adverse weather conditions and non-remunerative prices of poultry products among others. Based on the findings, it was therefore recommended that for poultry farmers to increase their profitability level, they should try to formulate their feeds by using locally available ingredients to reduce feed cost which constitute the highest percentage of total variable costs.
\end{abstract}

Keywords: Allocative, efficiency, layer, broiler, Sokoto, Nigeria

\section{Introduction}

The poultry industry plays important roles in the development of Nigerian economy by providing employment opportunities for the populace, thereby serving as a source of income to the people (FAO, 2005). Also, it provides a good source of animal protein in meat and eggs which have a high nutritional value (Abedullah et al., 2007). Animal protein sources include fish, eggs, poultry meat, beef, milk, bacon, pork and mutton. However, in Nigeria, the three most popular are fish, beef, and poultry meat (chicken) and eggs (Apantaku, 2006). The author pointed that poultry meat and eggs are palatable and generally acceptable with little or no cultural and religious boundaries in Nigeria. Chickens and eggs contribute to a nutritious, balanced diet, which is especially important for children, nursing mothers and people who are ill (ACIAR, 2009). Eggs are an excellent source of iron, zinc and vitamin A, all of which are essential for health, growth and wellbeing; egg is a complete protein with excellent quality (FAO, 2005;Tijjani et al., 2006).

Broiler and layer production are carried out in all parts of the country and there is neither religious, social, nor cultural inhibitions associated with their consumption (Etim and Udoh, 2006). Poultry meat is very tender and broiler enterprises have shorter production of only eight weeks and only five months are required to produce a laying hen (Alabiand Aruna, 2005). They argued that owing to these obvious advantages, large number of farmers, men and women go into poultry production, besides meeting the protein needs of the households. The importance of poultry to the national economy cannot be overemphasized as it has become a popular industry for smallholder farmers that have great contribution to the economy of Nigeria (Adebayo and Adeola, 2005).

\section{Literature Review}

\subsection{The Concept of Efficiency}

Efficiency of a production unit may be defined as how effectively it uses variable resources for the purpose of profit maximization, given the best production technology available (Battesse and Coelli, 2005). Efficiency, namely, the utilization of resources, is one of the most important topics of economic theory (Kumbhakar, 1991). Efficiency is the 
relationship between what an organization (producer, production unit, or any decision-making unit) produces and what it could feasibly produce, under the assumption of full utilization of the resources available, as stated by Kumbhakar and Lovell (2000).

Efficiency and productivity, although referring to distinct concepts derived from the production function, are interrelated and are common performance measures by which agricultural units are evaluated (Nmadu et al., 2014). The authors further explained that everyday meaning of the term 'efficiency' refers to a situation where resources are used to their capacity so that no resources are wasted. The origin of the operational concept of efficiency can be traced back to Farrell (1957) and has been widely used both in its original form and in various modifications, from which the following general discussion is derived. It is therefore a measure of efficiency accounting for a single output and multiple inputs. The efficiency of an economic unit is a holistic measure', in that it takes account of all resources used and all outputs produced in determining how well' or 'how effectively' the decision-making unit combines inputs to produce output (Nmadu et al., 2014).

\subsection{Allocative or Price Efficiency}

Unlike Technical Efficiency (TE), which is the maximum attainable level of output for a given level of production inputs, given the range of alternative technologies available to the farmer, Allocative Efficiency (AE) refers only to the adjustment of inputs and outputs to reflect relative prices, having chosen the production technology (Kalirajan and Shand, 1999). Chukwuji et al. (2006) maintained that allocative efficiency is achieved for a profit maximizing firm if the firm equates the value of marginal product to the unit price of the resource or the marginal factor cost. Allocative efficiency is a microeconomic concept which concentrates in considering disequilibria that might appear in the utilization of the existing factors of production with the techniques and methods given (Aji, 2011). The author stressed that AE refers basically to the choice of an optimum combination of inputs consistent with the relative factor prices. Also, Maximum or absolute allocative efficiency for a particular resource is confirmed if the efficiency for a particular resource is equal to one.

Allocative efficiency is a measure of firms' success in choosing an optimal set of inputs (Christopher et al., 2006). It is an indication of the gains that can be obtained by varying the input ratios on the bases of certain assumptions about future price structure of the product and factor markets and the goals of the firms. These assumptions are that producers seek to maximize their profits by choosing the best input combinations according to their relative prices in order to produce profit maximizing levels of output. Secondly, there exists perfect competition in the input and output markets. Also, the producers are assumed to be price takers and they have perfect information about the market. Finally, each production input is assumed to have the same quality for all producers.

Oh, and Kim (1980) defined allocative efficiency as the ratio of total cost of producing one unit of an output, using actual factor proportion in a technically efficient manner, to total cost of producing the same unit of output, using optimal factor proportions in a technically efficient manner. According to Lau and Yotopoulos (2001), a firm is said to be allocatively efficient if it maximizes profit, which implies that it was able to equate the value of marginal product (MVP) of each resource employed to its unit cost. This is the condition for profit maximization under perfectly competitive markets, which requires that the extra revenue generated from the employment of an extra unit of a resource must be equal to its unit cost (Akanni and Adeokun, 2004). The authors maintained that the efficient method of producing a product is that which uses the least amount of resources to get a given amount of the product. A production method that uses more of all physical resources than the alternatives in the production of a unit output is technically inefficient. Once technically inefficient methods of production have been eliminated, the issue of allocative efficiency would arise; that is, choosing among the technically efficient alternatives, the one that uses more of one input and less of another. This implies considering the cost of the inputs concerned in relation to the expected revenue they would generate. The least cost method is the most efficient. Firms, which are able to use the least cost method of production, are said to be perfectly allocatively efficient, implying that they operate at the point of tangency between an isoquant and iso-cost line intheir production frontier (Heady, 1952; Sankhayan, 1988).

\section{Methodology}

\subsection{Description of the Study Area}

The study was conducted in Sokoto State of Nigeria. The state, which consists of 23 Local Government Areas (LGAs), has its capital and seat of government located in Sokoto. According to Sokoto State Government Diary (SOSGD), the state is bordered to the North by Niger Republic, Zamfara state to the East and Kebbi state to the South and West, respectively. The state is located in the North-west geographical zone of Nigeria lying between latitudes $4^{0}-6^{0} 40^{\prime} \mathrm{N}$ and longitudes 11030'-13050' E. It covers a land area of 28,232.37 square kilometers (SOSGD, 2014).

According to SOSGD (2014), the state falls within the sub-Sahara ecological zone. This is open tsetse fly free grassland suitable for cultivation of grain crops and animal husbandry. The raining season is short with annual rain fall ranging from 500 to $1,300 \mathrm{~mm}$. Over eighty percent $(80 \%)$ of the inhabitants of Sokoto State practice one form of agriculture or the other (SMANR, 2013). They produce such crops as millets, guinea corn, maize, rice, potatoes, cassava, groundnut and beans for subsistence and produce wheat, cotton and vegetable for cash. Local craft such as blacksmithing, dyeing carving and leather works also play an important role in the economic life of the people of Sokoto State (SOSGD, 2014). The state is one of the fishes producing areas of the country. Thus, a large number of people along the River Basins engage in fishing as well (SMANR, 2013). 


\subsection{Data Collection and Sampling Procedure}

Data for this study were mainly primary and were obtained from layer and broiler farmers in 2013 using wellstructured and pre-tested questionnaire. Three Local Government Areas (LGAs) were purposively selected out of the twenty-three that make up Sokoto state due to large number of poultry farmers in theseLGAs. The sampling frame was established by obtaining a list of all the poultry producers from the Ministry of Animal Health and Fisheries Development and Poultry Farmers Associations in the LGAs. For the purpose of comparison, a Stratified Random Sampling Technique was used to group each LGA into three different sub-groups (strata) according to scale of production into small, medium and large enterprises for both broiler and layer producers. Lastly, simple random sampling through balloting was done to select 15 poultry farmers each from the small, medium and large-scale producers of both broilers and layers making a total of 45 broiler and 45-layer farmers in each LGA. The selection of 15 farmers from each stratum was due to uniform number of registered poultry farmers across the strata and across the three LGAs. In all, a total of 270 poultry farmers were selected for the study.

\subsection{Analytical Technique}

Cobb-Douglas Stochastic Production Function was used to estimate technical efficiency in broiler and layer enterprises, respectively.

\subsection{Theoretical Framework on Stochastic Frontier Production Function}

Considering a farmer using inputs $\mathrm{X}_{1}, \mathrm{X}_{2} \ldots . \mathrm{X}_{\mathrm{n}}$ to produce output $\mathrm{Y}$, efficient transformation of inputs into output is characterized by the production function $\mathrm{f}(\mathrm{x})$ which shows the maximum output obtainable from various input vectors. This approach is favoured because it accounts for the presence of measurement error in the specification and estimation of frontier production functions in that the former consists of low error terms. It should be made clear that the first error term $\left(V_{i}\right)$ accounts for the existence of technical inefficiency while the second $\left(U_{i}\right)$ accounts for factors such as measurement error in the output variable, diseases and the combined effect of unobserved inputs in production. The stochastic frontier production function is defined as:

$Y_{i}=f\left(X_{i}, \beta\right) \exp \left(V_{i}-U_{i}\right), i=1,2 \ldots \ldots . . n$

Where; $Y_{i}=$ production of the ith farm

$\mathrm{X}_{\mathrm{i}}=$ vector of input quantities of the ith farm

$\beta=$ Vector of unknown parameters of the ith farm

$\mathrm{V}_{\mathrm{i}}=$ random errors associated with random factors not under the control of farmers e. $\mathrm{g}$

weather and diseases.

$\mathrm{U}_{\mathrm{i}}=$ inefficiency effects (one sided error with $\mathrm{U} \geq 0$ ) i.e.Us are non-negative with technical

inefficiency in production.

$\mathrm{V}_{\mathrm{i}}-\mathrm{U}_{\mathrm{i}}=$ composite error term

$\mathrm{F}=$ functional notation

$\mathrm{i}=$ the farmer in question

$\mathrm{V}_{\mathrm{i}}$ is the usual symmetric notice associated with the random factors not under the control of the farm owner while the one-sided error $\mathrm{U}_{\mathrm{i}}$ and $\mathrm{U}_{\mathrm{i}} \geq 0$ captures technical inefficiency relative to the stochastic frontier.

The model simultaneously estimates the individual technical efficiency of respondents as well as determinants of technical efficiency. The estimation of stochastic frontier production makes it possible to find out whether the deviation in technical efficiencies from the frontier output is due to firm specific factors or due to external random factors. It provides estimates for technical efficiency by specifying composite error formulations to the conventional production functions (Coelli, 1995).

Technical efficiency of an individual farmer is defined as the ratio of the observed output to the corresponding frontier output, conditional on the levels of inputs used by the farmer. The technical efficiency of farmer (i) in the context of the stochastic production function in equation (1) is

$\mathrm{TE}=\mathrm{Y}_{\mathrm{i}} / \mathrm{Y}_{\mathrm{i}}^{*}$

$=f\left(X_{i} ; \beta\right) \exp \left(V_{i}-U_{i}\right) / f\left(X_{i} ; \beta\right) \exp \left(V_{i}\right)$

Where:

$\mathrm{Y}_{\mathrm{i}}=$ Observed value of output

$\mathrm{Y}^{*}{ }^{*}=$ Frontier output ( or potential output)

Note that the value of technical efficiency lies between zero and one. The most efficient farm will have value of one whereas the less efficient farm will have their efficiencies lying between zero and one. The parameters of the stochastic frontier production function model will be estimated by the method of maximum likelihood using the computer program Frontier version 4.1 (Coelli, 1994).

\subsection{Empirical Model for Technical Efficiency in Broiler Enterprise}

Following Aji (2011), the explicit form of the Cobb-Douglas Stochastic Frontier Production Function used to measure the technical efficiency in broiler enterprise was specified as:

$\ln \mathrm{Y}_{\mathrm{i}}=\ln \beta_{0}+\beta_{1} \ln \mathrm{X}_{1 \mathrm{i}}+\beta_{2} \ln \mathrm{X}_{2 \mathrm{i}}+\beta_{3} \ln \mathrm{X}_{3 \mathrm{i}}+\beta_{4} \ln \mathrm{X}_{4 \mathrm{i}}+\beta_{5} \ln \mathrm{X}_{5 \mathrm{i}}+\beta_{6} \ln \mathrm{X}_{6 \mathrm{i}}+\beta_{7} \ln \mathrm{X}_{7 \mathrm{i}}+\mathrm{V}_{\mathrm{i}-} \mathrm{U}_{\mathrm{i}} \ldots \ldots .$.

Where:

$\ln =$ logarithm to base e; $\beta_{1}-\beta_{7}=$ parameters to be estimated,

$\mathrm{Y}=$ Output of broiler (Naira),

$\mathrm{X}_{1}=$ Labour input (Mandays),

$\mathrm{X}_{2}=$ Value of feed and feed supplements (Naira), 
$\mathrm{X}_{3}=$ Value of Drugs and veterinary services (Naira),

$\mathrm{X}_{4}=$ Stock size (Number of birds),

$\mathrm{X}_{5}=$ Value of foundation stock (Day old chicks) purchased (Naira),

$\mathrm{X}_{6}=$ Operating expenses (Cost of water, electricity, repairs, transportation etc.),

$\mathrm{X}_{7}=$ Capital inputs (Depreciation on poultry buildings, equipment, interest payment, rent (Naira),

$\mathrm{V}_{\mathrm{i}}=$ Normal random errors which are assumed to be independent and identically distributed

having $\mathrm{N}\left\{0, \delta^{2}\right\}$ and

$\mathrm{U}_{\mathrm{i}}=$ Non-negative random variables associated with the technical inefficiency of the

entrepreneur.

It is assumed that the technical efficiency effects are independently distributed and arise by truncation (at zero) of the normal distribution with mean $\left(\mathrm{U}_{\mathrm{i}}\right)$ and variance $\left(\delta^{2}\right)$, where $\mathrm{U}_{\mathrm{i}}$ is specified as:

$-U_{i}=\delta_{0}+\delta_{1} Z_{1 i}+\delta_{2} Z_{2 i}+\delta_{3} Z_{3 i}+\delta_{4} Z_{4 i}+\delta_{5} Z_{5 i}+\delta_{6} Z_{6 i}+\delta_{7} Z_{7 i}+\delta_{8} Z_{8 i}+\delta_{9} Z_{9 i}+\delta_{10} Z_{10 i}+\delta_{11} Z_{11 i} \ldots$

Where:

$\mathrm{U}_{\mathrm{i}}=$ Technical inefficiency of the $\mathrm{i}^{\text {th }}$ broiler farm operator,

$\mathrm{Z}_{1 \mathrm{i}}=$ Age of the $\mathrm{i}^{\text {th }}$ broiler farm operator (Years),

$\mathrm{Z}_{2 \mathrm{i}}=$ Level of education of the $\mathrm{i}^{\text {th }}$ broiler farm operator (Number of years of schooling),

$\mathrm{Z}_{3 \mathrm{i}}=$ Farming experience of the $\mathrm{i}^{\text {th }}$ broiler farm operator (Years),

$\mathrm{Z}_{4 \mathrm{i}}=$ Household size of the ithbroiler farm operator (Numbers),

$Z_{5 i}=$ Extension contact of the $i^{\text {th }}$ broiler farm operator (Number of contacts with extension

officer during the last production year),

$Z_{6 i}=$ Credit status of the $i^{\text {th }}$ broiler farm operator (Amount obtained in Naira),

$\mathrm{Z}_{7_{\mathrm{i}}}=$ Membership of co-operative of the ithbroiler farm operator (Dummy variable, 1 for

membership, 0 otherwise),

$Z_{8 \mathrm{i}}=$ Gender of the $i^{\text {th }}$ broiler farm operator (Binary variable, Male=1, Female=2),

$\mathrm{Z}_{\mathrm{i}_{\mathrm{i}}}=$ Stock size of the $\mathrm{i}^{\text {th }}$ broiler farm operator (Number of birds),

$\mathrm{Z}_{10 \mathrm{i}}=$ Marital status of the $\mathrm{i}^{\text {th }}$ broiler farm operator $($ Single $=0$, Married $=2$, Divorced $=3$,

Widowed $=4$ ),

$Z_{11 i}=$ Scale of operation of the $i^{\text {th }}$ broiler farm operator (Small scale $=1$, Medium Scale $=2$, Large scale $=3$ ),

$\delta_{0}=$ Constant term and

$\delta_{1}-\delta_{11}=$ Maximum likelihood estimates that were estimated.

The above model was incorporated in the frontier model in determining the technical inefficiency of broiler and layer production enterprises. This was done following Kalirajan and Shand (1994) and Aji (2011).

\subsection{Empirical Model for Technical Efficiency in Layer Enterprise}

The model was specified as:

$\ln Y_{\mathrm{i}}=\ln \beta 0+\beta_{1} \ln \mathrm{X}_{1 \mathrm{i}}+\beta_{2} \ln \mathrm{X}_{2 \mathrm{i}}+\beta_{3} \ln \mathrm{X}_{3 \mathrm{i}}+\beta_{4} \ln \mathrm{X}_{4 \mathrm{i}}+\beta_{5} \ln \mathrm{X}_{5 \mathrm{i}}+\beta_{6} \ln \mathrm{X}_{6 \mathrm{i}}+\beta_{7} \ln \mathrm{X}_{7 \mathrm{i}}+\mathrm{V}_{\mathrm{i}-} \mathrm{U}_{\mathrm{i}}$

Where, variables $X_{1 i} X_{7 i}, \beta_{0}$ and $\beta_{1}-\beta_{7}$ are as defined in equation (4), $U_{i}$ is the same as in equation (5), $Y_{i}=$ value of output produced (Naira).

The model for the inefficiency factors for layers is the same as the model for inefficiency factors for broilers presented in equation (5). All the variables are as earlier defined.

\section{Results and Discussion}

\subsection{Allocative Efficiency in Layer and Broiler Enterprises}

The results of the estimation of maximum likelihood estimation of stochastic frontier production function for the measurement of allocative efficiency in layer and broiler enterprises are presented in Table 1. 


\begin{tabular}{|c|c|c|c|c|c|}
\hline & & \multicolumn{2}{|c|}{ Layers } & \multicolumn{2}{c|}{ Broilers } \\
\hline Variable & Parameters & Coefficients & t-ratio & Coefficients & t-ratio \\
\hline Constant & $\beta_{0}$ & 1.8009 & 1.0283 & 1.1114 & 0.5355 \\
\hline Labour & $\beta_{1}$ & -10.2352 & $-26.6797^{* * *}$ & -5.4662 & $-2.3074^{* *}$ \\
\hline Feeds & $\beta_{2}$ & 0.7211 & $4.5642^{* * *}$ & 0.1523 & 0.0741 \\
\hline Drugs & $\beta_{3}$ & 2.9957 & $59.6307^{* * *}$ & 0.0095 & 0.0048 \\
\hline Capital inputs & $\beta_{4}$ & -2.1330 & $-94.5107^{* * *}$ & 1.4697 & 0.7294 \\
\hline Foundation stock & $\beta_{5}$ & 2.9626 & $13.3000^{* * *}$ & 1.4170 & 0.7519 \\
\hline $\begin{array}{c}\text { Depreciation } \\
\text { Diagnostic statistics }\end{array}$ & $\beta_{6}$ & -13.3948 & $-47.8755^{* * *}$ & -9.0303 & $-4.0085^{* * *}$ \\
\hline \multicolumn{2}{|c|}{ Sigma squared $\left(\delta^{2}\right)$} & 16.0421 & $58.2362^{* * *}$ & 1.4775 & 0.3690 \\
\hline \multicolumn{2}{|c|}{ Gamma $(\gamma)$} & 1.1596 & $35.8752^{* * *}$ & 0.9850 & 0.3576 \\
\hline \multicolumn{2}{|c|}{ Log likelihood function } & 0.1105 & & 0.1612 & \\
\hline \multicolumn{2}{|c|}{ L-R test } & 3.9487 & & 0.2831 & \\
\hline
\end{tabular}

Table 1: Maximum Likelihood Estimates of Parameters of the Stochastic Frontier Cost Function for the Measurement of Allocative Efficiency of Layer and Broiler Producers

Source: Survey Analysis, 2013/Computed from Frontier 4.1c Version

Note: ***,**, and * Implies Statistical Significance at the 0.01, 0.05 and 0.10 Probability Levels, Respectively

From the results above, the estimated sigma squared for layer producers was 16.0421 and was significantly different from zero at the 0.01 probability level. This indicates a good fit and the correctness of the specified distributional assumption of the composite error terms in the estimated models for layer enterprises. The value of gamma for layer farmers was 1.1596 and also significant at the 0.01 probability level. The log likelihood function for layer and broiler farmers were 0.1105 and 0.1612 , respectively, while L-R test values were 3.9487 and 0.2831 , respectively.

An examination of the coefficients of the production factors revealed that the estimated coefficient of labour (10.2352) in the case of layer farmers was negative and statistically significant at the 0.01 probability level. This implies that an increase in the cost of labour decreased the total output of layer enterprises in the study area. This is in contrast to the findings of Bifaria et al. (2010) who reported a positive and significant influence of labour on total production. The coefficient of labour in the case of broiler production was -5.4662 and statistically significant at the 0.05 probability level. The negative coefficient also shows an inverse relationship between labour and output of production, implying that an increase in the cost of labour will lead to decrease in output in broiler enterprise.

The coefficient of feeds in layer enterprise was estimated to be 4.5642 , positive and statistically significant at the 0.01 probability level, implying that an increase in the cost of feed will result in corresponding increase in output in broiler production i.e. if feed input is increased by $1 \%$ holding other variables constant, output will increase by $4.5642 \%$. This is because feed has been identified as the largest cost item in poultry production, accounting for $65-70 \%$ of the total cost of production (Effiong and Umoh, 2010). Effiong and Onyenweaku (2006) reported that feed cost is the major important single cost item associated with poultry production due to the increase in costs of poultry feed ingredients such as maize, groundnut cake, soya bean meal and scarcity of wheat and corn offal. This underscores the importance of feed availability and affordability if poultry production is to be improved. The importance of feed in stimulating poultry production in Nigeria has been expressed by Oluyemi and Robert (1998). The relative importance of feed in poultry production cannot be over-emphasized. According to Sonaiya (2000), energy is the first essential nutrient in feed which should be available in large quantity in addition to crude fibre. That is why energy supplements may increase production significantly.

Adepoju (2008) reported that the major cost element in poultry egg production is the feed cost, which accounted for about $80 \%$ of the total cost of production. He also found the coefficient of feed to be negative implying that total revenue from egg production decreased with increase in feed cost. It implies that the factor allocation of feed is already in stage III of the classical production surface. For the feed input to be efficiently allocated, it has to be reduced.

Drugs and veterinary services for layer enterprises had an estimated coefficient of 2.9957 which was positive and significant at the 0.01 probability level. This suggests that increase in the cost of this variable input will lead to increase in output in layer enterprise. Olayide (1996) stressed that the fear of high mortality has been reduced to a minimal level with advancement in production of vaccines and drugs that prevent and cure the common diseases associated with birds.

The estimated coefficient of capital inputs in layer enterprise (-2.1330) was negative and statistically significant at the 0.01 probability level, implying that an increase in the amount of capital inputs used in egg production will lead todecrease in output. This may be due to the fact that farmers were incurring high fixed costs on buildings, machines and high interest rates. Therefore, for profit to be enhanced there is need to reduce operating expenses in the business. Itis however, in contrast to the findings of Ekpenyong (2002) that the coefficient of capital inputs was found to be positive and significant at the 0.10 probability level. This showed that output increased when the levels of capital inputs were increased.

The cost of foundation stock in egg production had a coefficient of 2.9626, statistically significant at the 0.01 level of probability, indicating that increase in the cost of birds will lead to increase in the output of egg production in Sokoto State. This is in consonance with Aji (2011) who found a significant and positive relationship between the cost of foundation stock and output of broiler and layer enterprises, implying that increase in the cost of foundation stock will bring about an increase in the total output in both enterprises. 
The results further showed that the estimated coefficient for the cost of depreciated assets in both egg (-13.3948) and broiler (-47.8755) enterprises were inversely related to output of production. The coefficients were both statistically significant at the 0.01 level of probability. This means that an increase in investment on the fixed capital inputs will lead to a decrease in the output realized in both enterprises. This means that poultry farmers in the study area need to reduce the expenditure on equipment on their farms to attain more output. This is in contrast to the findings of Bamiro et al. (2001) that the coefficient of depreciated cost of equipment was positive and significant at the 0.05 probability level. This suggests that the more the investment on equipment on the poultry farm, the better the attention received by the birds and thus, the higher the number of poultry eggs and income obtained by the poultry farmer.

\subsection{Frequency Distribution of Allocative Efficiency in Layer and Broiler Production Enterprises}

The frequency distribution of allocative efficiency of layer and broiler enterprises in Sokoto State is given in Table 2. The results revealed that the mean allocative efficiency of layer farmers was $91 \%$, meaning an average layer farmer could increase allocative efficiency by $9 \%$.

\begin{tabular}{|c|c|c|c|c|}
\hline & \multicolumn{2}{|c|}{ Layers } & \multicolumn{2}{c|}{ Broilers } \\
\hline Range & Number & Percentage & Number & Percentage \\
\hline $0.25-0.40$ & 1 & 0.74 & 5 & 3.70 \\
\hline $0.41-0.50$ & 2 & 1.48 & 8 & 5.93 \\
\hline $0.51-0.60$ & 3 & 2.22 & 16 & 11.85 \\
\hline $0.61-0.70$ & 9 & 6.67 & 23 & 17.04 \\
\hline $0.71-0.80$ & 6 & 4.44 & 21 & 15.56 \\
\hline $0.81-0.90$ & 25 & 18.52 & 32 & 23.70 \\
\hline $0.91-1.00$ & 89 & 65.93 & 30 & 100.00 \\
\hline Total & 135 & 100.0 & 135 & \\
\hline Mean & 0.91 & & 0.80 & \\
\hline Maximum & 0.99 & & 1.00 & \\
\hline Minimum & 0.31 & & 0.28 & \\
\hline Mean of best 10 & 0.98 & & 0.99 & \\
\hline Mean of least 10 & 0.57 & & 0.39 & \\
\hline
\end{tabular}

Table 2: Distribution of Broiler and Layer Farmers According to Farm Level Specific Allocative Efficiency Source: Field Survey, 2013

The predicted allocative efficiency range of layer farmers from Table 4.24 was between 0.25 and 0.99 . The maximum allocative efficiency of 0.99 and minimum of 0.31 were obtained for the farmers. The means of the best 10 and least 10 farmers were 0.98 and 0.57 , respectively. Thus, if a typical farmer in the sample was to achieve the optimum allocative efficiency of its efficient counterpart, then the typical farmer would require $8 \%$ cost saving [i.e., 1$(0.91 / 0.99) * 100]$. Also, the least allocatively efficient farmer will need a cost saving of about $42 \%$ [i.e., $1-(0.57 / 0.99) * 100]$. This showed that layer producers can increase allocative efficiency by $8 \%$ for them to be operating on the production frontiers.

Allocative efficiency of broiler farmers ranged from $0.25-1.00$. The mean allocative efficiency was $80 \%$, meaning that the average broiler farmer could increase allocative efficiency by $20 \%$. The maximum and minimum allocative efficiency of 1.00 and 0.28 were recorded for broiler farmers in the study area. The means of the best 10 and least 10 farmers were 0.99 and 0.39 , respectively. This implies that if a typical farmer in the sample was to achieve the optimum allocative efficiency of its most efficient counterpart, then the typical farmer would require a $20 \%$ cost saving [i.e., 1$(0.80 / 1.00) * 100]$. Similarly, the least allocatively efficient farmer will need a cost saving of $61 \%$ [i.e., 1- (0.39/1.00)*100]. Therefore, broiler farmers can increase allocative efficiency by $20 \%$, and if this is achieved, they will be operating on the production frontiers.

The minimum allocative efficiencies for layer and broiler enterprises were 0.31 and 0.28 , respectively. This therefore revealed a gross underutilization of resources because the best allocatively efficient farmers operated on the frontier and close to the frontier as depicted by the maximum allocative efficiencies of broiler and layer enterprises, respectively. This showed a serious disparity between allocatively efficient levels of best 10 and least 10 farmers, and to bridge the gap, the average farmers need to save $8 \%$ and $20 \%$ costs for layer and broiler enterprises, respectively, to be able to attain the frontier.

The results further showed that about $84 \%$ of layer farmers in the study area attained more than $80 \%$ allocative efficiency and only about $16 \%$ attained allocative efficiency of between $25-80 \%$. For broiler farmers, only about $46 \%$ attained allocative efficiency above $80 \%$ and about $54 \%$ attained allocative efficiency of between 25 - 80\%.

\section{Conclusion and Recommendations}

The study concluded that poultry farmers in the study area were not fully allocatively efficient in their production activities and that the overall productivity in the two enterprises could be improved substantially. Based on the findings of the study, it is recommended that extension activities should focus on training of the farmers on improved production management to enable them use the available resources efficiently and increase productivity.Farmers should be 
encouraged to formulate their feeds by using locally available ingredients to reduce feed cost which constitute the highest percentage of total variable costs.

\section{References}

i. Abedullah, A., Maqbool, A., \&Bukhsh, K. (2007).Issues and economics of poultry production: A case study of Faisalabad, Pakistan. PakistanVeterinary Journal, 27(1), 25-28.

ii. Adebayo, O. O. and Adeola, R. G. (2005). Socio-Economic Factors Affecting Poultry Farmers inEjigbo Local Government Area of Osun State. Journal ofHuman Ecology, (18): 39-41.

iii. Adepoju, A. A. (2008). Technical Efficiency in Egg Production in Osun State.International Journalof Agricultural Economics and Rural Development. 1(1): 7-14

iv. Aji, D. A. (2011).Profitability and Efficiency of Broiler and Layer Production Enterprises inNiger State, Nigeria. An unpublished M. Sc. Thesis submitted to the Department of Agricultural Economics and Extension Technology, School of Agricultural Technology,Federal University of Technology, Minna, Niger State.

v. Akanni K. A. and Adeokun O. A. (2004): Resource efficiency differential in small-scale food cropproduction in Obafemi Owode Local Government Area, Ogun State. FAMAN Journal.7(1): 1-15

vi. Alabi, R. A. and Aruna, M. B. (2005).Technical Efficiency of Family Poultry Production inNiger-Delta, Nigeria.Journal of Central European Agriculture, 6 (4):531-538.

vii. Apantaku, S. O. (2006). Analysis of participation of farmers in participatory poultry production research in Lagos State, Nigeria. Livestock Research for Rural Development 18(7).Retrieved fromhttp:/ / www.lrrd.org/ lrrd18/ 7/ apan18094.htm

viii. Australian Centre for International Agricultural Research (ACIAR).(2009). Improving village chicken production: A manual field workers and trainers, The Monograph series. 30- 31pp.

ix. Bamiro, O. M., Shittu, A. M., Olutokun, A. S. (2001). Private feed production as cost reductionstrategy: Effects on profitability of poultry business in Ogun State, Nigeria. The Ogun Journal of Agricultural Sciences, 1(1): 37-51.

x. Battese, G. and T. Coelli, (2005). A Model for Technical Inefficiency Effects in a Stochastic FrontierProduction Function for Panel Data, Empirical Economics, 20: 325-332.

xi. Bifarin, J. O., Alimi T., Baruwa, O.I.and Ajewole, O.C.(2010).Determinant of Technical, and Economic Efficiencies in the Plantain (Musa spp.) Production Industry, Ondo State, Nigeria. In: Proceeding of International Conference on Banana \& Plantain in Africa pp. 199-210.

xii. Christopher, O. C., Odjuvwuederhie, E. I., O'raye, D. O. and William, J. O. (2006). A Quantitative Determination of Allocative Efficiency in Broiler Production in Delta State, Nigeria. Agriculturae Conspectus Scientificus. 71(1): 2126.

xiii. Chukwuji, C. O., Inoni, O. E. Ogisi, O. D. and Oyaide, W. J. (2006). A Nigerian QuantitativeDetermination of Allocativeefficiency in Broiler Production in Delta State, Agriculture ConspectusScientificus, (71): 21-26.

xiv. Coelli, T. J. (1994). A guide to FRONTIER version 4.1: A computer program for stochastic frontierproduction and cost function estimation. CEPA Working Papers, No. 7/96, ISBN 1863894950, Department of Econometrics, University of New England, Armidale, pp. 33.

xv. Coelli, T.J. (1995) Estimators and Hypothesis Tests for a stochastic Frontier Function: A Monte Carlo Analysis. The Journal of Productivity Analysis. 6: 247-268.

xvi. Ekpenyong, U. U. (2002). An Economic Evaluation of Egg and Broiler Enterprise in AbakMunicipality of Akwa Ibom State. An Unpublished B.Sc Project. University of Calabar, Cross River State

xvii. Etim, N. A. and Udoh, E. J. (2006). Efficiency of Resource Utilization: The Case of BroilerProduction by Urban Farmers in Uyo Metropolis. (ASN) Proceedings of the40th AnnualConference of the Agricultural Society of Nigeria held at National Root Crops Research Institute, Umudike, Abia State, 16-20th October, 2006. Pp 213-218.

xviii. Farrel, M., (1957). The Measurement of Productive Efficiency, Journal of Royal Statistical Society,A. 120 (3) 253281.

xix. Food and Agriculture Organization. (2005). Animal production and health, paper 50, FAO, Rome

xx. Heady, E. O. (1952). Economics of agricultural production and resource use. Prentice - Hall,Inc., New York. 345pp.

xxi. Kalirajan, K. P. and Shand, R. T. (1994).Frontier Production Functions and Technical EfficiencyMeasures.Journal of Economic Survey.13 (2) 149-172.

xxii. Kumbhakar, S. C. and Lovell K. C. A. (2000). Stochastic Frontier Analysis. Cambridge UniversityPress. Cambridge. $327 \mathrm{pp}$.

xxiii. Kumbhakar, S.C., Ghosh, S. and McGuckin, J. T. (1991) A Generalized Production FrontierApproach for Estimating Determinants of Ined ciency in U.S. Dairy Farms. Journal of Business \& Economic Statistics. 9 (3): 279-86.

xxiv. Lau L. and Yotopoulos P.,(2001). A Test for Relative Efficiency and Application to IndianAgriculture. American Economic Review, 61: 94-109.

xxv. Oh, H. S. and Kim, J. B. (1980). A partial analysis of technical efficiency and returns to scale in Korean rice production. Journal of Rural Development. 3(4): 1-10.

xxvi. Olayide, S. O. and Heady, E. O. (1996). Introduction to Agricultural Production Economics. IbadanUniversity Press. Ibadan. Pp 84-96.

xxvii. Oluyemi, J.A. and F. A. Roberts, (1998). Poultry Production in Warm WetClimates. $2^{\text {nd }}$ Edition,Macmillan Publishers, London and Basing Stroke, U. K Pp 49-51.

xxviii. Sankhayan P. L. (1988). Introduction to the Economics of Agricultural Production. Prentice Hall of India Private Ltd, New Delhi, India 233 pp. 
xxix. State Ministry of Agriculture and Natural Resources (2013).State Ministry of Agriculture and Natural Resources annual report, Sokoto State, Nigeria, 56pp.

xxx. Sokoto State Government (SOSG) (2014).Sokoto State Government Diary. Yearly Publication by Home Affairs Department. Sokoto State.371 pp.

xxxi. Sonaiya, E. B. (2000). Background Poultry Production for Socio-Economic Advancement of theNigerian Family: Requirement for Research and Development. Nigeria Poultry Science Journal 1:88-107.

xxxii. Tijjani, A. A., Alimi, T. and Adesiyan, A.T., (2006).Profit Efficiency among Nigerian Poultry Egg Farmers: A case study of Aiyedoto Farm settlement, Lagos, Nigeria. Research Journal ofAgricultural Biological Sciences, 2(6): 256261. 